Educational Needs, Inclusionand Diversity, a textbook. Buckingham: Open University Press. 14. Hanko G. 'Towards an inclusive school culture - but whathappened to Eltons affective curriculum?', British Journal of Special Education, 30 (3), 125-131. Direct Link: Abstract PDF (60K),2003. 15. Hodkinson A. 'Inclusive and special education in the English educational system: historical perspectives, recent developments and future challenges', Research in Education, 2010, 73, 15-29. 16. Judge B. 'Inclusive education: principles and practices', in K.Crawford (ed) Contemporary Issues in Education. Norfolk: PeterFrancis, 2003. 17. Rustemier S. \& Vaughan M. (Segregation Trends - LEAs in England 2002-2004. Bristol: CSIE, 2000. 18. Warnock M. Sspecial educational needs - a new look', Centre for Disability Studies [online at http://www.leeds.ac.uk/disability-studies/archiveuk/archframe.htm.

УДК 37.022:001.53

Олександр Жосан

\title{
ІСТОРІОГРАФІЯ ПРОБЛЕМИ РОЗВИТКУ ВІТЧИЗНЯНОЇ ШКІЛЬНОЇ НАВЧАЛЬНОЇ ЛІТЕРАТУРИ В 20-х - 80-х РОКАХ ХХ СТОЛІТТЯ
}

Жосан О. Е. Історіографія проблеми розвитку вітчизняної шкільної навчальної літератури в $20-\mathrm{X}-80-\mathrm{x}$ роках XX століття.

У статті подається аналіз історіографії проблеми розвитку шкільної навчальної літератури у 1921-1989 роках: праць науковців, учителів, керівників освіти; спеціальних історіографічних досліджень 3 питань підручникознавства, словникарства i книгознавства; історико-педагогічних досліджень, опублікованих з 1921 по 2012 рік.

Ключові слова: джерело дослідження, історіографія проблеми, шкільна навчальна література, підручникознавство, словникарство, книгознавство.

Жосан А. Э. Историография проблемы развития отечественной школьной учебной литературы в 20-х - 80-х годах XX века

В статье представлен анализ историографии проблемы развития школьной учебной литературы в 1921 - 1989 годах: работ ученых, учителей, руководителей образования; специальных историографических исследований по учебниковедению, лексикографии и книговедению; историко-педагогических исследований, опубликованных с 1921 по 2012 год.

Ключевые слова: источник исследования, историография проблемы, школьная учебная литература, учебниковедение, лексикография, книговедение.

Josan O. E. The historiography of development problems of the national school educational literature in the $20 \mathrm{~s}-80$ s of the twentieth century.

Author has analyzed the historiography of the problem of school educational literature in 1921 - 1989 years: works of scientists, teachers, educational leaders, special historiographical researches on theory of educational literature, lexicography and Bibliology, historical and pedagogical researches published from 1921 to 2012.

Keywords: scientific sources, historiography of the problem, school educational literature, theory of educational literature, lexicography, Bibliology.

Фундаментом наукових історико-педагогічних праць, як справедливо підкреслюють науковці [3; 4; 11], є історіографія конкретної проблеми, що надає змогу визначити наукову новизну та теоретичне значення дослідження. 
Історіографічний пошук стосовно нашої проблеми показав, що на всіх етапах досліджуваного періоду розвитку навчальної літератури науковці різних галузей науки, педагоги-практики, керівники освіти публікували присвячені цій проблемі праці. Крім того, вітчизняні й зарубіжні науковці здійснювали і здійснюють нині спеціальні історіографічні дослідження 3 проблем підручникознавства, словникарства, книгознавства, а також історико-педагогічні й історико-книгознавчі дослідження.

Метою статті $є$ спроба здійснити аналіз історіографії проблеми нашого дослідження «Тенденції розвитку шкільної навчальної літератури в Україні (20-ті-80-ті роки XX століття)».

Період 1921-1932 років у розвитку явища шкільної навчальної літератури знайшов відображення в тогочасних працях радянських науковців, методистів і вчителів

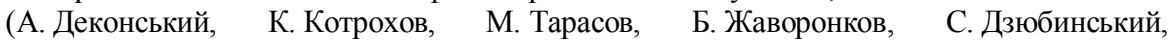
С. Сингалевич, Я. Столяров, Г. Іваниця, П. Блонський та інші). Бачення змісту i структури навчальних книг відображалося в працях К. Сивкова, М. Покровського, I. Катаєва, О. Кудрявцева, О. Стражева, О. Александрова, П. Самухіна, Я. Ряппо, Д. Скуратівського, О. Кулініча та інших.

Стосовно розвитку мовознавства й лексикографії, С. Бевзенко [2] зазначає, що перші теоретичні розробки 3 української лексики й фразеології з'явилися лише наприкінці 20-х років у вигляді окремих розділів у загальних курсах української мови за редакцією Л. Булаховського («Загальноприступний курс української мови», «Загальний курс української мови», «Підвищений курс української мови»), які у цілому відповідали тогочасному станові української лексикології та стали орієнтирами для складання різноманітних словників.

Період 1933-1959 років у розвитку процесів підручникотворення знайшов відображення в публікаціях із проблем створення шкільних підручників, методики їх використання в навчально-виховному процесі, в узагальнювальних працях із радянської теорії шкільного підручника, а також у деяких історико-педагогічних дослідженнях. Концепція підручника як основного засобу навчання була в основному завершеною в середині 30-х pp. Н. Крупською. Одним із перших дослідників ілюстративного оформлення шкільного підручника був К. Кузьминський. Основні дидактичні й методичні вимоги до шкільної навчальної літератури визначили А. Смирнов, С. Виноградов, К. Корнілов, С. Чавдаров та інші.

Дослідження в галузі історії українського мовознавства, зокрема й лексикографії, майже не здійснювалися. Перша важлива робота в цей період з'явилася лише в 1957 році («Дослідження з мовознавства в Українській РСР за сорок років»).

Стан підручникотворення в Україні в 1941-1944 роках вивчений слабко. У радянській історіографії 40-х - 80-х років простежується думка, що освітній процес на окупованих землях припинився. У дослідженнях 90-х років освітній процес на окупованих землях теж вивчався мало. Більш об'єктивно й неупереджено ця проблема розглядалася науковцями діаспори (Д. Кислиця, З. Кузеля, К. Паньківський та інші). Вивченням освіти України в часи німецької окупації грунтовно займаються сучасні дослідники С. Беллецца, Л. Задорожна, П. Мазур, В. Офіцинський, О. Потильчак, А. Скоробогатов, Б. Соколов, Г. Стефанюк, Д. Титаренко та інші Певну увагу вони приділяють зокрема й основним підходам до підручникотворення. Торкається цієї проблеми і В. Оліфіренко у своїй монографії, присвяченій історії підручника 3 літератури [8]. Окрім того, означені питання розглядаються у працях зарубіжних дослідників М. Дацишиної, Б. Сржабкової та інших. Грунтовних досліджень проблем навчальної літератури в період окупації не здійснювалось. 
До середини XX ст. історія становлення і розвитку методики навчання та підручникотворення не була предметом уваги науковців. Лише в 50-х рр. опубліковані праці, у яких стисло проаналізовано підручники 3 української мови (І. Білодід, Л. Симоненкова). Наприкінці 50-х рр. було видано методичні статті та посібники для вчителів Г. Давидова, В. Мазуренко, А. Кінкулькіна, у яких автори висвітлювали окремі аспекти історії підручникотворення [9].

На аналізованому хронологічному етапі в середині 50-х рр. подальший розвиток отримала теорія підручника, яка в історіографії проблеми відображена грунтовними статтями Є. Перовського, Н. Менчинської, С. Чавдарова. Частково проблематика підручникотворення вісвітлена в працях радянських істориків освіти: Л. Бущика, М. Лисенка, В. Масальського, П. Підкасистого, 3. Равкіна та ін.

На процесі вивчення проблем навчальної літератури негативно позначилася політика правлячої партії: масові репресії (ув'язнення, заслання або фізичне знищення українських науковців, керівних кадрів освіти й педагогів-практиків). У цей період призупинила розвиток українська, натомість формується радянська офіційна історикопедагогічна історіографія, зокрема щодо шкільної навчальної літератури, яка не передбачала ії об'єктивного висвітлення.

Підходи до проблем формування змісту освіти, методики викладання різних предметів та визначення місця навчальної літератури в цьому процесі в 20-50-х роках знайшли певне відображення й у працях сучасних науковців: Л. Березівської, О. Дятлової, О. Пометун, Н. Стоюхіної, О. Сухомлинської та інших.

Період 1960-1989 років у розвитку шкільної навчальної літератури в історіографії відобразився висвітленням у постановах партії та уряду, наукових дослідженнях та методичних розробках. Цікавими й корисними були спроби історико-педагогічного дослідження українського шкільного підручника (А. Бугай, О. Мазуркевич, 1960 р.). У 1971 році О. Боданська захистила кандидатську дисертацію «Підручник як засіб активізації пізнавальної діяльності учнів (на матеріалі підручників історії та географії для 5-8 класів)». Ці питання знайшли відображення в публікаціях лабораторії «Психологічні проблеми побудови шкільних підручників», створеної в 1968 р. (співробітники групи: Г. Граник, С. Бондаренко, Л. Концева, Є. Божович, О. Юдіна). Теорія шкільного підручника знайшла свій подальший розвиток у творчості В. Сухомлинського. Його науковий доробок окреслює найважливіші аспекти цієї проблеми, а саме: шкільний підручник як об'єкт теоретичного аналізу; формування в учнів уміння працювати з підручником; інформаційна культура педагога - важливий чинник розвитку уміння працювати 3 книгою (опосередкований шлях формування вміння вчитися) [7, с. 201].

У цей період 3'являються найважливіші праці 3 історії методики викладання української мови (М. Грищенко, Ф. Жилко, С. Левченко, В. Масальський, І. Матвіяс, Л. Рожило, С. Чавдаров та інші). Важливе місце у них відводилося й навчальній літературі.

Історія методів та засобів викладання іноземних мов грунтовно досліджена i описана І. Рахмановим. Окрім того, вивченням цих проблем, зокрема й питань підручникознавства, займалися Д. Ганшина, М. Гез, І. Грузинська, Г. Гольдштейн, Ю. Жлуктенко, Р. Кузнєцова, Р. Розенберг, С. Фоломкіна, 3. Цвєткова та інші. У 60-70-х роках роботи Т. Передерій, П. Зеленського, Г. Рогової, В. Цетлін, О. Миролюбова, Л. Садчикової та інших висвітлювали проблеми удосконалення змісту шкільних програм, поліпшення результативності використання підручників та інших видів компонентів навчально-методичного комплексу. Педагогічні праці 80-х - 90-х років XX століття і початку XXI століття (Л. Биркун, П. Гурвич, А. Климентенко, О. Миролюбов, 
В. Берека, Б. Лапідус, $\quad$ В. Плахотник, $\quad$ С. Полат, $\quad$ Т. Передерій) характеризуються полемікою про подальші перспективи вдосконалення змісту шкільної іншомовної освіти, методів викладання, зокрема щодо ролі й місця навчальної літератури в цих процесах.

Основні підходи до формування змісту, структури та методичного апарату підручників із суспільствознавства окреслено в публікаціях відомих радянських науковців, методистів, учителів 60-х - 70-х рр. (М. Адамський, Г. Артемьєва, В. Бойков, Н. Дайрі, А. Іванченко, О. Курдюмова, В. Мазуренко, А. Нікітін, Я. Соколов, М. Сиродоєв, М. Овчиннікова, Г. Шарапов та інші).

У 80-х рр. були видані фундаментальні праці з проблем теорії підручника, у яких досліджувалися його зміст, структура, методичний апарат, функції, принципи побудови і використання. Це роботи відомих радянських науковців: В. Бейлінсона «Арсенал освіти: характеристика, підготовка, конструювання навчальних видань», Л. Доблаєва «Смислова структура навчального тексту та проблема його розуміння», Д. Зуєва «Шкільний підручник», І. Лернера «Дидактичні основи методів навчання», Я. Мікка «Оптимізація складності навчального тексту», І. Лернера і М. Шахмаєва «Теоретичні проблеми шкільного підручника». Саме на цьому етапі остаточно сформувалися теоретичні засади шкільного підручника, що знайшли відображення у випусках теоретичного щорічника «Проблеми шкільного підручника» (перший номер вийшов у лютому 1974 року, а 20-й - у 1991 році).

Протягом 60-х - 80-х років здійснювалися історико-педагогічні дослідження щодо розвитку методики викладання природничих i математичних дисциплін (Ю. Полянський, Д. Трайта, А. Бугайов, Г. Маслова та інші).

Проблеми шкільного підручникотворення висвітлювалися в працях відомих дидактів (Ю. Бабанський, Н. Бібік, М. Махмутов, О. Савченко та ін.).

У 80-ті роки вперше на науковому рівні була проголошена думка про необхідність вивчення історії підручника. Цю ідею обгрунтували М. Тупальський, В. Рокітянський та М. Скаткін.

Своєрідним підсумком досліджень у галузі теорії шкільного підручника стала колективна праця науковців Тартуського університету на чолі з Я. Мікком «Підвищення якості навчальної літератури» (1985 р.).

3-поміж історіографічних праць цього періоду зі словникарства варто виокремити такі: «Мовознавство на Україні за п’ятдесят років» (1967р.) та «Розвиток мовознавства в УРСР. 1967-1977» (1980р.), «Історія української мови». У структурі радянської лексикографії в кінці 60-х років з'явилася нова галузь - навчальна лексикографія. У 70-х-80-х роках починаються грунтовні й системні дослідження цього явища (Г. Богачова, В. Гак, П. Денисов, Ж. Дюбуа, К. Дюбуа, В. Морковкін, С. Поліковська, А. Супрун та інші).

Проголошена реформа загальноосвітньої і професійної школи 1984 р. спричинила появу низки праць, присвячених іï теоретичним засадам, стратегічним завданням, напрямам і ходу, у яких певною мірою розглядалися й питання навчальної літератури. У руслі політики перебудови в наукових та методичних працях 3 проблем загальної середньої освіти другої половини $80-\mathrm{x}$ років спостерігалося суттєве згортання ідеологічних підходів та перехід до об'єктивного наукового висвітлення й дослідження проблем. У 1986 р. серію публікацій і жваву дискусію на сторінках педагогічної преси відкрила публікація М. Адамського «Яким має бути підручник із суспільствознавства»; у 1988 р. з'явилися праці Г. Граник, С. Бондаренко, І. Журавльова, Л. Зоріної, Л. Концевої, у яких подавалися нові погляди на проблеми підручникознавства.

Проблеми розвитку навчальної літератури були також у полі уваги українських науковців, що проживали за межами України. Здійснюючи спеціальні дослідження або в 
контексті висвітлення розвитку освіти тією чи іншою мірою досліджуваної проблеми торкалися науковці української діаспори Г. Ващенко, Б. Кравців, Р. Ільницький, I. Городецький, Л. Кисілевська-Ткач, Б. Шкандрій, Ю. Бобровський, В. Радзикевич, М. Дейко, П. Волиняк, В. Марунчак та інші. На жаль, переважна більшість перерахованих вище праць стала доступною для науковців, що проживали в Україні, лише після проголошення незалежності.

Проблеми розвитку навчальної літератури $20-\mathrm{x}-80$-х років цікавлять і сучасних науковців. Свідченням цього $є$ численні публікації з історії підручникотворення в щорічних випусках заснованого 1999 р. Інститутом педагогіки НАПН України збірника наукових праць «Проблеми сучасного підручника», проведення низки науковопрактичних конференцій та семінарів. Грунтовне різнобічне дослідження проблем підручника для школи І ступеня здійснила Я. Кодлюк у докторській дисертації «Теорія і практика підручникотворення у галузі початкової освіти України (1960-2000рр.)» [8]. Значний внесок у вивчення проблем підручникознавства зробив І. Смагін у докторській дисертації «Методичні засади створення i функціонування підручників із суспільствознавчих предметів у загальноосвітній школі України (1920-1990рр.)» [9]. Проблеми розвитку навчальної літератури в досліджуваний нами період тією чи тією мірою розглядалися також у кандидатських дисертаціях Н. Кузьменко, А. Зякун [5], П. Мороза, Г. Розлуцької, Н. Богданець-Білоскаленко, Л. Височан, О. Пасічника та інших.

Деякі аспекти функціонування шкільної навчальної літератури розкрили: Л. Потапова у кандидатській дисертації «Розвиток національної школи в Україні (19171933 рр.)» (1998р.); В. Липинський у докторській дисертації «Становлення і розвиток нової системи освіти в УСРР у 20-ті роки» (2001р.); Л. Березівська у докторській дисертації «Організаційно-педагогічні засади реформування шкільної освіти в Україні у ХХ столітті» (2009 р.) [3].

Певну інформаційну цінність мають для нас інші історико-педагогічні дослідження сучасних науковців (статті, посібники, дисертації тощо), де в рамках сучасної історикопедагогічної парадигми в контексті різноманітних проблем побіжно згадуються ті чи ті питання розвитку окремих видів навчальної літератури (О. Адаменко, Н. Гупан, С. Головко, М. Кукурудзяк, О. Любар, О. Пометун, М. Собчинська, М. Стельмахович, Б. Ступарик, О. Сухомлинська, Д. Федоренко, М. Ярмаченко та інших).

Проблеми розвитку навчальної літератури в $60-\mathrm{x}-80-\mathrm{x}$ роках розглядали в своїх дослідженнях Р. Арцишевський, В. Волков, I. Гудзик, Г. Касьянов, С. Клепко, Т. Харламова, Т. Лукіна, О. Савченко, О. Удод та ін.

Сучасні дослідники теоретичної лексикографії приділяють увагу i окремим проблемам розвитку навчальної лексикографії досліджуваного нами періоду (В. Авраменко [1], О. Кровицька, Л. Струганець, В. Сімонок та ін.).

Важливим напрямом нашого дослідження $є$ вивчення книгознавчого аспекту розвитку навчальної літератури. Становлення української книгознавчої наукової школи, у структурі якої значне місце посідало й підручникознавство, відбулося на початку 1920-х років. Її пріоритетними напрямами були дослідження в галузі історії української книги (С. Маслов, П. Попов, О. Балицький, С. Сфремов), періодики (В. Ігнатієнко), мистецтва книги (М. Макаренко, Д. Щербаківський), теорії та практики укладання українського бібліографічного репертуару (Ю. Меженко, Я. Стешенко, С. Маслов, П. Іноземцев). Розвивалося книгознавство і в українських емігрантських осередках (С. Сірополко, Л. Биковський та ін.).

Розгром радянського книгознавства, зокрема й українського, стався 1931 року. Гострій критиці були піддані «ідеалістичні та націоналістичні засади буржуазного 
українського книгознавства», діяльність Інституту книгознавства, журналу «Бібліологічні вісті». Майже до кінця 1950-х років в УРСР не з'явилося жодної вагомої праці $з$ книгознавства, а сам термін «книгознавство» вийшов 3 активного наукового вжитку.

Відродження радянського книгознавства починається в 1960-х роках. 3-поміж книгознавчих дисциплін найактивніше розвивається історія книги, яка нині $є$ вже усталеною науковою дисципліною. Українське історичне книгознавство представлене вагомими працями І. Свєнціцького, І. Огієнка, С. Маслова, П. Попова, І. Крип’якевича, I. Каганова, С. Петрова, Я. Запаска, Я. Ісаєвича, В. Фрис, О. Дзюби. У 90-х роках XX на початку XXI століття в Україні активно розвиваються науки на межі книгознавства й інших дисциплін, зокрема кодикологія, книжкове пам'яткознавство, історія видавничої справи та ін. Історико-книгознавчі статті публікуються на сторінках наукових видань. 3'явилися нові теоретичні праці з книгознавства: В. Буран, Г. Ковальчук, Я. Ісаєвич, I. Тимошенко та інші.

Отже, історіографічний аналіз проблеми нашого дослідження засвідчив нерівномірність іï розвитку на різних етапах формування педагогічної думки, а також залежність цієї галузі наукового дослідження від усвідомлення ролі й місця навчальної літератури в навчально-виховному процесі на конкретному етапі розвитку педагогіки і школи в досліджуваний період. Окрім того, доцільно зауважити, що науковцями вивчався переважно підручник. Інші ж види навчальної літератури об'єктами грунтовних досліджень не були.

Радянську шкільну навчальну літературу як явище, систему ще ніхто грунтовно не досліджував. Тому як окремий об'єкт історико-педагогічних досліджень вона залишається недостатньо вивченою.

\section{Література}

1. Авраменко В. І. Розвиток навчальної термінологічної лексики у процесі розбудови української системи освіти (кінець XIX ст.- початок 1930-х рp. XX століття) : дис. ... кандидата пед. наук: 13.00.01 / Валентина Іванівна Авраменко. - К., 2003. - 173 с. 2. Бевзенко С. П. Історія українського мовознавства. Історія вивчення української мови / С. П. Бевзенко. - К. : Вища школа, - 1991. - 231 с. 3. Березівська Л. Д. Організаційно-педагогічні засади реформування шкільної освіти в Україні у XX столітті : дис. ... доктора пед. наук: 13.00.01 / Лариса Дмитрівна Березівська. - К., 2009. - 871 с. 4. Гупан Н. М. Розвиток історії педагогіки в Україні (Історіографічний аспект): дис. ... доктора пед. наук: 13.00.01/ Гупан Нестор Миколайович. - К., 2001. - 486 с. 5. Зякун А. І. Навчальна література з історії кінця 80-х 90-ті pp. XX ст.: історіографічний аналіз : дис. ... кандидата історичних наук: 07.00 .06 / Зякун Алла Іванівна. - К., 2002. - 184 с. 6. Ісаєвич Я. Д. Українське книгознавство: етапи розвитку/ Я. Д. Ісаєвич// Вісник Львівського університету. Серія: Книгознавство. - 2006. - Вип. 1. - С. 7-19. 7. Кодлюк Я. П. В. О. Сухомлинський про шкільний підручник / Я. П. Кодлюк// Історія педагогіки у структурі професійної підготовки вчителя: зб. наук. праць Кам'янець-Подільського держ. пед. університету. Кам'янець-Подільський : Абетка Нова, 2002. - Вип. 3 (Т. 2). - С. 199-208. 8. Оліфіренко В. В. Підручник 3 української літератури : історія i теорія/ В. В. Оліфіренко. - Донецьк : Східний видавничий дім, 2003. - 324 с. 9. Смагін I. I. Методичні засади створення i функціонування підручників із суспільствознавчих предметів у загальноосвітній школі України (1920-1990 рр.) : дис. ... доктора пед. наук: 13.00.02 / Смагін Ігор Іванович. - К., 2011. - 562 с. 10. Сухомлинська О. В. Історикопедагогічне дослідження та його «околиці»/ О.В. Сухомлинська// Шлях освіти.2005. - № 4. - C. 43-47. 